\title{
ENTOAÇÃO DAS INTERROGATIVAS TOTAIS DO ESPANHOL PRODUZIDAS POR UM MADRILENHO E POR UM PROFESSOR DE ESPANHOL, FALANTE DE PORTUGUÊS BRASILEIRO DE CURITIBA
}

\section{Intonation of Spanish Interrogative questions by a native from Madrid and a Spanish teacher, Brazilian Portuguese speaker from Curitiba}

\section{Pollianna MILAN, PPG-UFPR ${ }^{1}$}

RESUMO: Esta pesquisa investigou a entoação de interrogativas totais do espanhol feitas por um professor que tem esse idioma como língua estrangeira (LE). Ele é brasileiro, dialeto curitibano, e diz falar o espanhol da variedade madrilenha. Por isso, foi gravado também um madrilenho que serviu como informante controle. As gravações foram feitas em situações de fala espontânea e induzida e os resultados mostram que o informante de LE altera a entoação (entre adequada e inadequada) destas interrogativas conforme o ambiente em que está.

PALAVRAS-CHAVE: prosódia; Espanhol; língua estrangeira; dialeto curitibano.

ABSTRACT: This research has investigated the intonation of Spanish interrogatives made by a Brazilian teacher of Spanish. The participant has a Brazilian Portuguese dialect from Curitiba, and he reported he speaks Spanish with variant from Madrid. Besides, one native speaker of Spanish from Madrid was also recorded as reference for comparison. The recordings were made in situation of semi and spontaneous speech, and the results showed that the Brazilian participant modifies his Spanish intonation (varying from correct to incorrect) depending on the environment.

KEYWORDS: prosody; Spanish; foreign language; Curitiba.

\section{INTRODUÇÃO}

O aprendizado de uma língua estrangeira (LE) exige uma série de requisitos para que o aluno consiga aprender essa nova língua a ponto de ser um falante proficiente. Uma dessas exigências, e até mesmo um dos maiores desafios nesta aquisição, é o aprendiz ser capaz de falar essa LE sem criar ruídos na comunicação, ou seja, ser compreendido em suas intenções de fala, como conseguir fazer uma pergunta neutra inteligível, por exemplo, sem que ela pareça ao ouvinte uma ironia. Essa capacidade de comunicação perpassa estudos da prosódia, o que quer dizer que o aprendiz precisa perceber que há diferenças tanto no nível segmental quanto suprassegmental entre a LE e a sua língua materna (de agora em diante LM), pois, a prosódia da LE (seu nível

\footnotetext{
${ }^{1}$ Mestranda do Programa de Pós-Graduação em Estudos Linguísticos pela Universidade Federal do Paraná (UFPR)
} 
suprassegmental), foco da presente pesquisa, normalmente não é a mesma da LM.

Desta forma, o objetivo da pesquisa é analisar a produção de interrogativas espanholas totais feitas por um brasileiro (com dialeto curitibano), professor de espanhol, para verificar se ele faz essas interrogativas com a entoação da LE. No caso de falantes do português brasileiro (de agora em diante $\mathrm{PB}$ ) que aprendem a língua espanhola (ou castelhana) como LE, diversos estudos (PINTO, 2009; FONTROTCHÉS, 2011; DIAS, 2012) têm demonstrado as dificuldades desses aprendizes em fazer a entoação da língua espanhola adequadamente. Esta dificuldade está relacionada, principalmente, às interrogativas espanholas, que exibem uma maior distinção quando comparadas às interrogativas do PB. Para esta pesquisa, foram analisadas as interrogativas totais, ou seja, aquelas que comportam apenas como resposta um não ou um sim.

Não se tem conhecimento, pelo menos por enquanto, de pesquisas nessa área de entoação com falantes do dialeto curitibano, por isso, a intenção do trabalho é analisar esse público para contribuir com o mapeamento prosódico do espanhol como língua estrangeira no Brasil e, assim, apontar as dificuldades no processo de aquisição dessa LE. Além disso, parte-se do princípio de que falantes de espanhol como LE (de dialeto curitibano), assim como os aprendizes de alguns outros estados brasileiros (PINTO, 2009; FONT-ROTCHÉS,2011; DIAS,2012), repetirão as dificuldades prosódicas no momento de produzir interrogativas totais, normalmente fazendo as características entoacionais do PB no espanhol.

Os resultados obtidos através desse estudo permitirão orientar ações didáticas específicas que buscam aprimorar a entoação do espanhol por parte dos brasileiros. Em especial, visa-se diminuir o sotaque estrangeiro, bastante comum na comunicação hispânico brasileira.

As gravações para este artigo foram obtidas em falas espontâneas e induzidas. Além do professor de espanhol (dialeto curitibano) - que afirma usar a variedade madrilena nesse idioma estrangeiro - foi gravado (em fala induzida), um madrilenho para ser o informante controle desse estudo. $\mathrm{O}$ foco de análise das interrogativas totais será o núcleo do enunciado, no qual aparecem, principalmente, as marcas da interrogação, seja com o final em ascensão ou em queda. 


\section{AS INTERROGATIVAS TOTAIS DO ESPANHOL}

Em algumas línguas, a entoação é a única responsável por diferenciar as frases declarativas das interrogativas. Isso vale, por exemplo, para o espanhol e o português brasileiro (QUILIS, 1988; NAVARRO TOMAS, 1974). E, apesar de ambos os idiomas carregarem essa característica, a prosódia de cada um deles tem suas particulares que, por isso mesmo, os tornam distintos entre si. Então, nessa pequena revisão teórica, a intenção é apontar quais são essas diferenças, para assim, perceber se elas podem interferir ou não no processo de ensino-aprendizagem de um idioma estrangeiro, nesse caso, o espanhol aprendido por brasileiros.

Navarro Tomas (1974) lembra que o final do grupo melódico interrogativo do espanhol pode ser de três tipos: ascendente, descendente ou circunflexo. Sobre as interrogativas totais, que são o foco de pesquisa deste artigo, elas costumam ser caracterizadas por um final da curva melódica com ascensão, diferente das declarativas neutras, que não têm essa subida no final.

As perguntas totais, também chamadas de absolutas, nas quais se têm como resposta à pergunta um sim ou um não, apresentam este movimento ascendente no núcleo do enunciado, neste caso, no final da frase. Nos pressupostos da teoria autossegmental métrica (AM) - inicialmente proposta por Pierrehumbert, em 1980, para a entoação do inglês e, depois, aperfeiçoada por outros pesquisadores como Laad (1996), Lucente e Barbosa (2007), Moraes (2008) e Moraes e Colamarco (2007) - a configuração da curva melódica de uma interrogativa absoluta no espanhol é L*H\%, ou seja, quer dizer que a última palavra do enunciado, que é o núcleo, costuma ter uma frequência fundamental (vibração de cordas vocais, medida em Hertz-Hz) baixa na sílaba acentuada $\left(\mathrm{L}^{*}\right)$ - a letra "L" significa low (baixo) e o asterisco quer dizer que a sílaba é tônica - e depois tem uma ascensão na última sílaba átona (H\%); o "H" é high (alto) e o porcentual simboliza a fronteira (final) do enunciado. Esta notação da pergunta absoluta do espanhol é descrita por pesquisadores como Sosa (1999). O autor explica que, desde o início, a altura do tom em um enunciado interrogativo espanhol é mais alto que sua afirmação correspondente, essa característica, segundo ele, ocorre nos variados dialetos desse idioma. "Esta frecuencia fundamental incrementada es uno de los indicadores de que se trata, en efecto, de una pregunta y no de una afirmación"2 (p.150). Por causa disso, as interrogativas do espanhol já levam em seu início o ponto

\footnotetext{
2“"Esta frequência fundamental incrementada é um dos indicadores de que se trata, em efeito, de uma pergunta e não de uma afirmação". Tradução livre da autora.
} 
de interrogação invertido, que adverte ao leitor que se trata de uma pergunta e que, se for feita a leitura da frase, ela deve ter uma frequência mais alta do que a leitura de uma afirmativa. Sobre o núcleo das interrogativas, Sosa (1999) analisou distintos dialetos, desde hispano-americanos (portenho, de Bogotá, mexicano, portorriquenho, de Caracas e de Havana) até alguns casos pensinsulares. A respeito do madrilenho, objeto de estudo desse artigo, o núcleo é ascendente (com a configuração L*H\%) - esta notação métrica, aliás, foi encontrada para todas as mostras peninsulares do pesquisador (como Sevilha e Barcelona) e para variantes hispano-americanas como as de Bogotá, a mexicana e a portenha.

As variedades caribenhas analisadas pelo pesquisador (venezuelana, cubana e portorriquenha) apresentam uma configuração oposta às demais e, por isso mesmo, bastante particulares. Nelas, o final da interrogativa se apresenta com uma queda e com o formato chamado de circunflexo $\left(\mathrm{H}^{*} \mathrm{~L} \%\right)$, porque há uma ascensão e, logo em seguida, uma descida, semelhante ao que ocorre com o formato desse acento no PB. "Ya decía Obregón (1981) que el uso de la construcción entonativa descendente en la formación de la pregunta sin palabra interrogativa es uno de los rasgos más típicos de la entonación venezolana"3 (Sosa, p. 206).

Quilis (1988) adverte ainda para a existência de um tipo de pergunta absoluta em espanhol que também costuma ter uma queda no núcleo. Trata-se das perguntas que têm a presença de um elemento gramatical que, por si só, é interrogativo. Palavras como "quem", "como", "onde", "por que" e "quando" são algumas dessas que já carregam consigo esta marca.

En otras palabras, podemos decir que si el significado de un enunciado está indicado de un modo suficientemente claro por el texto (palabra, estructura gramatical), la entonación no desempeña prácticamente ningún papel, pero si el sentido no está suficientemente indicado en el texto, la entonación funciona a pleno rendimiento ${ }^{4}$ (p. 39).

Ainda para o enunciado interrogativo absoluto, Quilis (1988) também confirma a sua configuração, de um modo geral, com o núcleo de forma ascendente, apesar de não citar a configuração $\mathrm{L} * \mathrm{H} \%$ do modelo AM.

\footnotetext{
3 “Já dizia Obregón que o uso da construção entoativa descendente na formação da interrogação, sem palavra interrogativa, é uma das características mais típicas da entoação venezuelana”. Tradução livre da autora.

44 Em outras palavras, podemos dizer que o significado do enunciado está indicado de um modo suficientemente claro pelo texto (palavra, estrutura gramatical), a entoação não desempenha praticamente nenhum papel, mas, se o sentido não está suficientemente indicado no texto, a entoação funciona a pleno rendimento. Tradução livre da autora.
} 
Navarro Tomás (1974), um dos pioneiros nos estudos da entoação do espanhol, descreve minuciosamente o que acontece com a interrogativa absoluta a partir de conceitos de semitons:

En la primera sílaba acentuada la voz se eleva tres o cuatro semitonos sobre la altura media que a esa misma sílaba corresponde en el tono enunciativo. El descenso que se produce en las sílabas siguientes abarca de ordinario siete u ocho semitonos. La evolución progresiva del descenso se manifiesta especialmente en las sílabas acentuadas. Aunque guiadas por estas, las inacentuadas se mueven con mayor libertad dentro de esa misma dirección. El descenso comprende hasta la última sílaba fuerte o hasta la que inmediatamente le precede. El final de la frase en la pregunta absoluta es siempre ascendente. La amplitud de la elevación final representa aproximadamente cinco o seis semitonos (...). Si la frase termina con sílaba acentuada, la elevación se produce dentro de ella misma. Si hay alguna sílaba débil después del último acento, su pronunciación continúa en la inflexión ascendente final ${ }^{5}$ (p. 101-102).

Estudos mais recentes como os de Font-Rotchés (2011) corroboram as pesquisas de Sosa (1999), Quilis (1988) e Navarro Tomás (1974), de que as perguntas totais do espanhol, de uma maneira geral, terminam com ascensão no núcleo.

Font-Rotchés (2011) descreve as interrogativas do espanhol por meio do sistema chamado "Análisis Melódico del Habla" (AMH), que leva em consideração a curva melódica nas vogais, ou seja, a frequência delas (medida por Hertz), para se chegar a cálculos porcentuais de quanto essas vogais sobem no núcleo, em comparação com o pré-núcleo do enunciado interrogativo. Resumidamente, a pesquisadora demonstra que os padrões entoacionais das perguntas absolutas costumam ser i) com final ascendente (subida de 70\%) para perguntas de caráter neutro; ii) interrogativas absolutas com ascensão de $40 \%$ a $60 \%$; iii) padrão ascendente-descendente, que ocorre apenas em contextos bastante específicos e iv) corpo ascendente, cuja curva da ascensão começa bem antes do núcleo e só sobe.

A "Nueva gramática de la lengua española" (2011) descreve como próprio das interrogativas totais, na maior parte das variedades do espanhol, a curva final

\footnotetext{
${ }^{5} \mathrm{Na}$ primeira sílaba acentuada, a voz se eleva três ou quatro semitons sobre a altura média que a essa mesma sílaba corresponde o tom enunciativo. A queda que se produz nas sílabas seguintes corresponde a sete ou oito semitons. A evolução progressiva da queda se manifesta especialmente nas sílabas acentuadas. Mesmo que guiadas por essas, as inacentuadas se movem com maior liberdade dentro dessa mesma direção. A queda vai até a última sílaba forte ou até a que a imediatamente precede. O final da frase da pergunta absoluta é sempre ascendente. A amplitude da elevação final representa aproximadamente cinco ou seis tons (...). Se a frase termina com sílaba acentuada, a elevação se produz dentro dela mesma. Se existe alguma sílaba átona depois do último acento, sua pronúncia continua na inflexão ascendente final. Tradução livre da autora.
} 
marcadamente ascendente.

\begin{abstract}
Se inicia en tono medio, a continuación se produce un descenso del tono durante la primera sílaba acentuada seguido de un descenso del tono que ocupa el cuerpo central de la interrogación hasta el núcleo, donde se produce la trayectoria marcadamente ascendente de la interrogación típica española. Cuando la secuencia contiene una palabra oxítona final, todo el movimiento terminal grave y ascendente se concentra en esta sílaba ${ }^{6}(\mathrm{p} .467-468)$.
\end{abstract}

Essa nova gramática explica, também, que em apenas algumas regiões específicas de fala castelhana se produz a interrogativa absoluta com o núcleo em queda, como nas Canárias, Astúrias, Galícia, Catalunha e em locais de espanhol caribenho como Porto Rico, Cuba e Venezuela.

\title{
AS INTERROGATIVAS TOTAIS DO PORTUGUÊS BRASILEIRO
}

A preocupação em descrever nesse artigo como ocorrem as interrogativas absolutas do PB se deve ao fato de essa diferenciação entoacional - de uma língua para a outra - poder influenciar o falante brasileiro (nesta pesquisa, de dialeto curitibano) a produzir interrogativas espanholas com características de sua língua materna. Se isso ocorre ou não, será descrito nos resultados. Vale, porém, destacar aqui algumas diferenças importantes entre as interrogativas absolutas do português e as do espanhol, que mostram, inclusive, possíveis dificuldades que um falante brasileiro - aprendiz de espanhol como LE - pode ter.

Moraes (2008) caracteriza as perguntas totais do PB com uma subida na primeira sílaba acentuada, seguida por uma contínua queda até o final da sílaba pré-acentuada e com uma nova subida no núcleo, na sílaba acentuada, seguida por uma outra queda nas sílabas posteriores, não acentuadas. Pela notação AM, o pesquisador descreve essas perguntas com a configuração $\mathrm{L}+\mathrm{H}^{*} \mathrm{~L} \%$.

Lucente e Barbosa (2007) transcrevem a entoação das perguntas absolutas do PB também como L+H*L\% quando não há a ocorrência de foco estreito na última palavra, ou seja, "forma-se um pico ao meio da vogal acentuada e sua queda coincide com o final da vogal” (p.8) e, a notação $\mathrm{L}^{*}+\mathrm{HL} \%$, quando há foco de contraste na última palavra, ou seja, "em que a f0 (frequência fundamental) inicia sua subida alinhada ao meio da consoante da sílaba acentuada; continua sua subida até o final da vogal, forma um pico e inicia sua descida" (p.8).

\footnotetext{
${ }^{6}$ Se inicia em tom médio, a continuação se produz uma queda de tom durante a primeira sílaba acentuada seguida de uma queda de tom que ocupa o corpo central da interrogação até o núcleo, onde se produz a trajetória marcadamente ascendente da interrogação típica espanhola. Quando a sequência contém uma palavra oxítona final, todo o movimento final grave e ascendente se concentra nesta sílaba. Tradução livre da autora.
} 
Há ainda outra questão interessante a ser lembrada aqui. Alguns estudos têm demonstrado que o padrão entoacional das interrogativas do PB pode variar segundo a acentuação da palavra sobre a qual recai o acento frasal (ou seja, o núcleo). Abraçado et al. (2007) explica que as interrogativas terminadas em oxítonas apresentaram um movimento de frequência fundamental (f0) descendente até o último constituinte prétônico do núcleo, seguido de uma subida na tônica do núcleo. Já para as sentenças terminadas com vocábulos paroxítonos e proparoxítonos ocorre um movimento semelhante às oxítonas, diferenciando-se pelo núcleo que apresenta movimento ascendente na tônica e descendente na pós-tônica (configuração circunflexa). Ou seja, quando as interrogativas do PB terminam em palavras oxítonas, elas finalizam a curva entoacional com ascensão (igual à maioria das curvas interrogativas totais do espanhol); já quando terminam com paroxítonas e proparoxítonas, a curva tende a ter o formato circunflexo. Sobre isso, também escreveu Quilis (1988). Ao comparar as duas línguas em questão, o pesquisador explica que o enunciado interrogativo absoluto do espanhol termina em ascensão, enquanto que no PB ele só finaliza com esta configuração quando tem no núcleo frasal uma palavra oxítona. Nos demais casos, as interrogativas absolutas terminam em queda.

Diante dessa revisão teórica, é possível prever que um falante nativo de $\mathrm{PB}$, ao falar espanhol como LE, tenderá a realizar com sucesso as interrogativas totais finalizadas em palavras oxítonas, pois, como demonstrado acima, a entoação destas sentenças (tanto em espanhol como em PB) é a mesma, uma curva entoacional em ascensão (provavelmente, no caso do PB, porque falta material fonético suficiente para que ocorra a descida na pós-tônica e, assim, para que a curva apresente uma queda no final, caracterizando o núcleo circunflexo dessas interrogativas neste idioma).

Já não se pode dizer, por outro lado, que esse falante terá a mesma facilidade com as perguntas terminadas em palavras paroxítonas e proparoxítonas, pois, neste caso, as curvas melódicas do espanhol madrilenho costumam terminar em ascensão e, as do PB, em queda (movimento circunflexo).

\section{ALGUNS ESTUDOS SOBRE A AQUISIÇÃO DE ESPANHOL COMO LE POR FALANTES DE PB}

Estudos sobre como os brasileiros (de algumas regiões do país), aprendizes de espanhol como LE, produzem as interrogativas totais castelhanas demostram as 
dificuldades que esses falantes têm em produzir corretamente a entoação espanhola. Antes de citar algumas destas dificuldades, porém, é importante destacar que a intenção de pesquisar se um informante de dialeto curitibano é capaz de produzir a entoação adequada das interrogativas totais do espanhol deve-se ao fato de não haver pesquisas das interrogativas totais, até onde se tem conhecimento, sobre a entoação do espanhol como LE por curitibanos.

Pinto (2009) pesquisou falantes de espanhol como LE nascidos no Rio de Janeiro e comparou a prosódia deles com a de madrilenhos, porque os livros didáticos usados pelos cariocas costumam ser produzidos em Madri. A conclusão a que chegou, sobre as interrogativas totais do espanhol como LE, é que esses falantes transferem as características entoacionais de sua língua materna para o espanhol, pois realizam um contorno melódico final circunflexo (igual ao do PB) nas interrogativas totais e não ascendente, como em espanhol.

Oliveira (2011) pesquisou brasileiros nascidos em Goiás que moram em Barcelona e falam espanhol como LE e chegou a conclusão, também, de que há processos de transferência de entoação do PB para o espanhol, porque "os corpos dos enunciados produzidos pelos brasileiros são fundamentalmente planos, esse provavelmente é o "perfil melódico" típico do espanhol falado por brasileiros." (p.96) Além disso, Oliveira (2011) conclui que os brasileiros "formulam enunciados neutros que podem ser facilmente interpretados como enfáticos ou suspendidos pelos espanhóis." (p.97)

Dias (2012) pesquisou duas brasileiras, de Florianópolis, falando espanhol como LE na variante colombiana. A conclusão a que chegou é a que, nas interrogativas absolutas que têm como núcleo uma oxítona, ambas conseguiram produzir a entoação espanhola, ou seja, com ascensão no final da curva melódica. Quando no núcleo havia palavras paroxítonas ou proparoxítonas, porém, houve alteração entre o padrão final ascendente, descendente e circunflexo na produção do espanhol como LE por essas aprendizes.

\section{METODOLOGIA}

O corpus dessa pesquisa foi obtido de duas maneiras: gravações (feitas com o gravador digital da marca Olympus) de fala espontânea em sala de aula; e gravações feitas com o programa Audacity (baixado da internet, versão 2.0.5) para falas induzidas, 
de frases interrogativas criadas pelos informantes a partir de um texto que lhes dava o contexto da pergunta que deveria ser formulada mentalmente e, depois, falada. Neste segundo caso, as frases criadas foram gravadas em laboratório com tratamento acústico, de modo a assegurar a qualidade dos registros e garantir a fidelidade dos dados a serem analisados, sem a interferência de ruídos.

A pesquisa contou com dois informantes: um brasileiro de 24 anos nascido em Curitiba (PR), que aprendeu espanhol como LE. Ele é graduado em Licenciatura Dupla Português-Espanhol pela Universidade Federal do Paraná (UFPR) e ministra aulas de espanhol no Centro de Línguas Estrangeiras (Celin), da mesma instituição. Esse informante diz falar o espanhol com a variedade madrilena e será identificado aqui como informante de LE. Por isso, o segundo informante dessa pesquisa - considerado o informante controle - é um madrilenho que está há cerca de um ano em intercâmbio em Curitiba. Ele leciona aulas de espanhol na UFPR como professor convidado, tem 27 anos, e será identificado nesse artigo como informante nativo.

Foi utilizado o programa Praat (versão 5373) para a análise das curvas entoacionais dos dois informantes e também para etiquetar a notação métrica do núcleo do enunciado.

Primeiramente, as gravações foram feitas com o informante de LE. Foram gravadas aproximadamente 11 horas de aulas ministradas por ele para uma turma de Espanhol Básico 1 do Celin. Em seguida, desse corpus, foram selecionadas apenas as interrogativas totais produzidas espontaneamente por esse informante, que resultaram em 49 enunciados desse tipo. Foram analisados, porém, 41 deles, porque as outras 8 interrogativas eram retóricas e não se tratavam de perguntas totais neutras (objeto de estudo desse trabalho). Apesar de a pesquisadora ter se sentado próximo à mesa do professor para realizar as gravações das aulas, a qualidade das gravações ficou aquém do esperado (com ruídos e com diversas curvas melódicas que não foram desenhadas pelo programa Praat, pois não foram reconhecidas). Por isso mesmo, além de analisar as interrogativas produzidas espontaneamente em sala de aula (muitas delas, apenas com a audição), optou-se por gravar, com esse informante, perguntas induzidas.

Nessa segunda etapa, foi entregue ao informante de LE um guia impresso com 40 pequenos textos que narravam situações para as quais ele deveria formular perguntas totais em espanhol, como por exemplo: "acabas de llegar a tu classe (eres professor) y 
necesitas saber si los alumnos han hecho la tarea. ¡Pregúntales!"7 O informante foi instruído a ler cada um dos contextos, criar a frase mentalmente e, logo em seguida, dizê-las de maneira mais espontânea possível, imaginando-se na situação descrita. Dessa vez, a gravação foi feita pela pesquisadora em uma sala de aula, somente com o informante de LE, sem os alunos. Mesmo assim, a sala não tinha tratamento acústico e, por isso, as frases ditas não ficaram com uma boa gravação. Então, o informante de LE foi convidado a regravar a pesquisa (foi explicado a ele que havia muitos ruídos nas gravações anteriores). Dessa vez, a gravação foi feita em um laboratório acusticamente isolado localizado na própria UFPR. Foi replicado o teste dos 40 contextos, em que ele deveria criar perguntas. Apesar de replicar o teste, o informante não ficou sabendo, em nenhum momento, do que se tratava a pesquisa.

Após as gravações com o informante de LE, foram feitas as gravações com o informante nativo (madrilenho). Para ele, foi aplicado apenas o teste com os 40 pequenos textos (a partir dos quais deveria criar interrogativas totais em espanhol) e as gravações foram feitas diretamente no laboratório com tratamento acústico para garantir a qualidade do som captado.

Apesar das dificuldades encontradas nas gravações, foram analisadas, para o informante de LE, as gravações feitas em sala de aula (com ele ministrando aula, em fala espontânea), as gravações feitas em sala de aula (apenas a pesquisadora e ele, em fala induzida) e as gravações feitas em laboratório (em fala induzida).

Para o madrilenho, foram analisadas as gravações realizadas em laboratório (em fala induzida). Ao todo, então, foram analisadas 116 interrogativas totais produzidas pelo informante de LE (41 delas de fala espontânea, em sala de aula; 36 em fala induzida gravadas em sala de aula sem alunos e; 39 em fala induzida gravadas em laboratório). Para o nativo, foram analisadas 55 interrogativas totais produzidas em fala induzida em laboratório (o mesmo produziu mais de 40 interrogativas, porque para um mesmo contexto ele formulou questões diferentes). Já o informante de LE não chegou a ter 40 interrogativas para cada um dos contextos porque, em alguns deles, a pergunta não foi feita de modo satisfatório para a pesquisa (em vez de pergunta absoluta, ele fez pergunta parcial).

Após a coleta e separação das gravações, as interrogativas absolutas foram

\footnotetext{
7 “Acaba de chegar a sua aula (você é professor) e precisa saber se os alunos fizeram a tarefa. Pergunte isso a eles!" Tradução livre da autora.
} 
abertas no programa Praat para se observar o final da curva melódica. Foi analisado apenas o núcleo frasal das interrogativas com base nos pressupostos da teoria autossegmental métrica (AM). Foi feita a etiquetagem desse núcleo a partir do modelo AM para ser computada, posteriormente, a quantidade de interrogativas absolutas feitas pelo informante de LE com a configuração L*H\% (do espanhol de Madri) e se houve interrogativas espanholas feitas com a configuração $\mathrm{L}+\mathrm{H}^{*} \mathrm{~L} \%$ (do português brasileiro), nesse último caso, a produção seria consequência da transferência da prosódia do PB para o espanhol. Para as interrogativas feitas pelo madrilenho também foi feita a etiquetagem com o intuito de confirmar se o mesmo produzia perguntas totais com a configuração L*H\%, descrita pela teoria e pesquisas anteriores.

\section{RESULTADOS}

Sobre as 55 perguntas totais produzidas pelo madrilenho, a grande maioria delas teve a curva melódica tal como o descrito pelas teorias da área (citadas acima). Foram produzidas 46 interrogativas absolutas $(84 \%)$ com o formato métrico L*H\%, ou seja, com ascensão no núcleo.

Isso é possível observar nos exemplos abaixo:

¿Conoces algún cardiólogo?

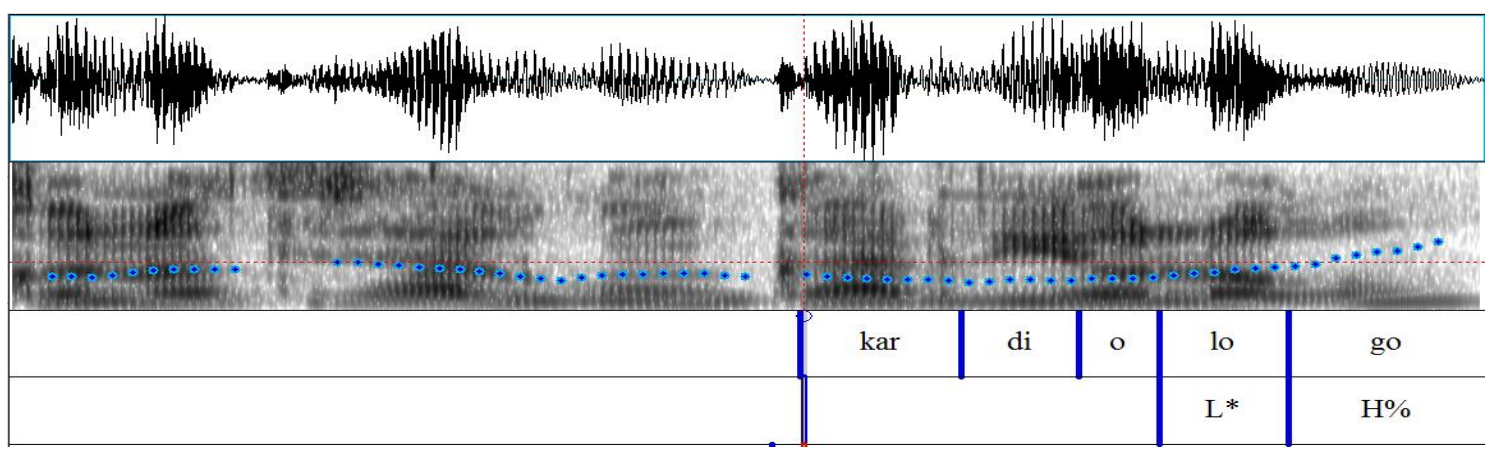

Laura, ¿te importaría llevarme? 


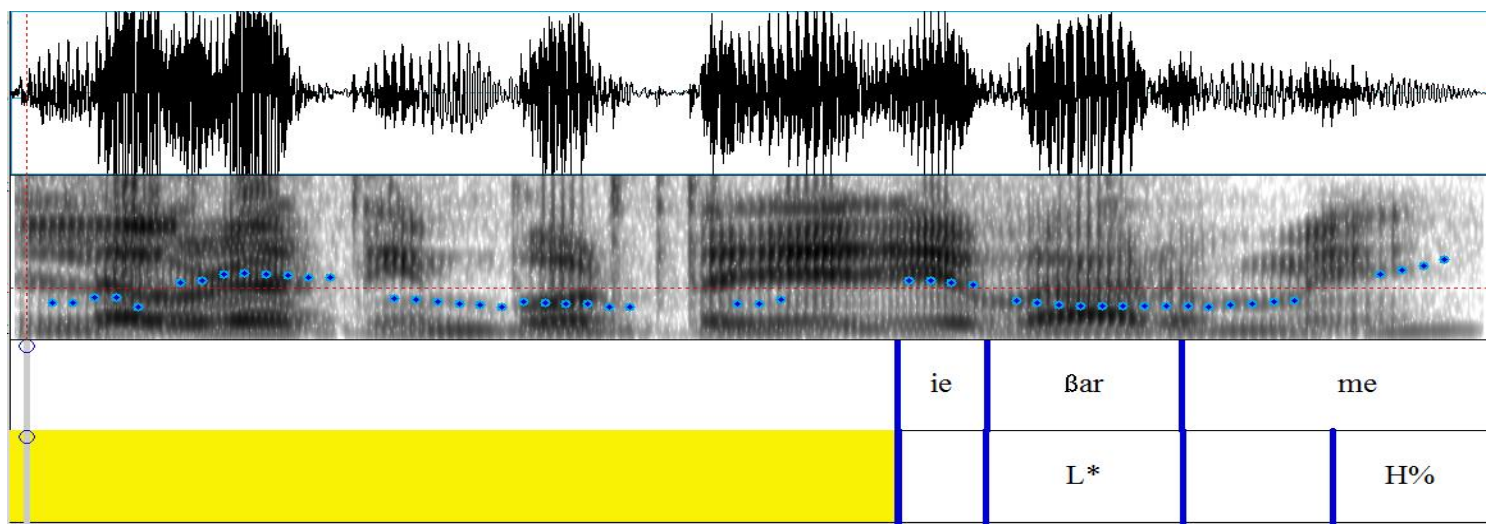

Interessante observar, porém, que o madrilenho produziu 9 interrogativas (16\%) com uma curva melódica com queda no final, semelhante à prosódia das interrogativas absolutas do português. Apesar de alguns autores, como Quilis (1988), explicarem que isso é possível no espanhol peninsular para as interrogativas que levam conteúdo gramatical de pergunta como "por que" ou "onde", esses 9 casos encontrados não se encaixam nessa explicação, pois são perguntas sem marcas gramaticais de interrogação. Sosa (1999) explica, por outro lado, que isso pode acontecer em interrogativas totais que foram feitas sem serem neutras, ou seja, que apresentam alguma intenção a mais no enunciado que não é apenas a de obter uma resposta sim ou não. Ou ainda, Sosa (1999) explica que as interrogativas totais madrilenhas que não terminam em ascensão também podem ter sofrido algum efeito externo, como do ambiente onde estava o informante, nervosismo na gravação, entre outros fatores.

As 9 se configuraram da seguinte maneira:

¿Habéis hecho los ejercicios?

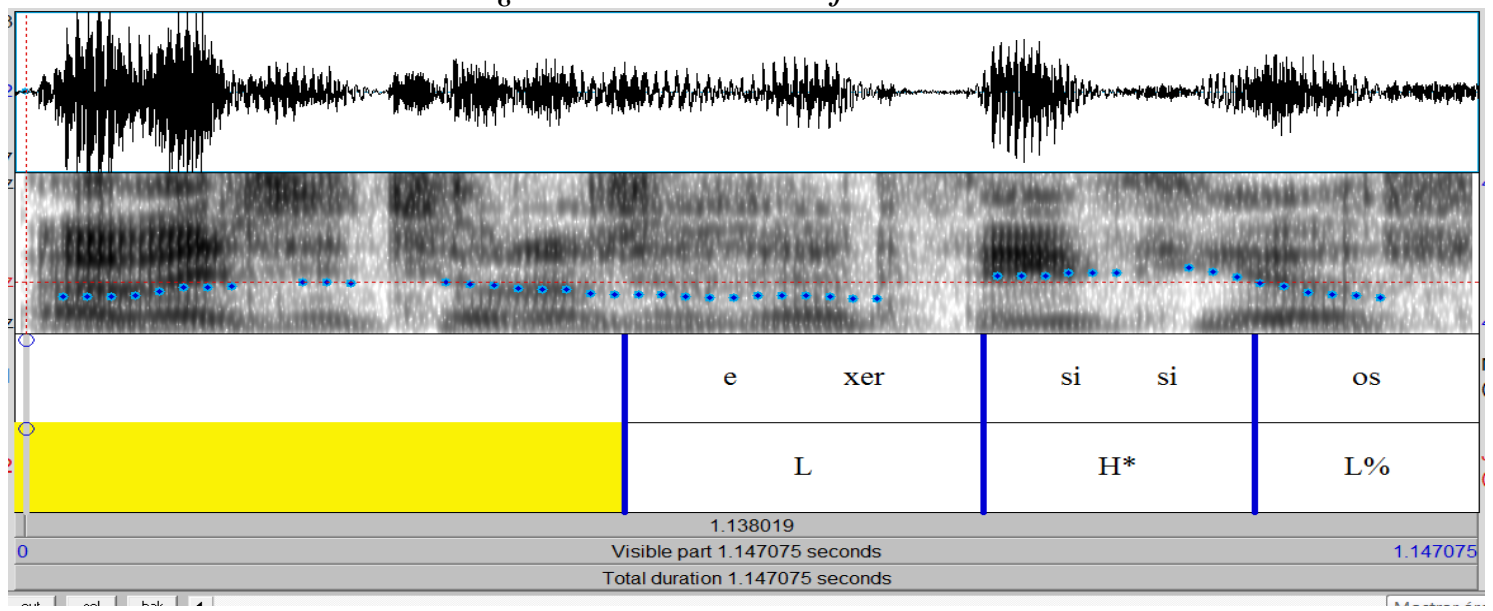


Disculpe, ¿ya ha salido el autobús que va a Salamanca?

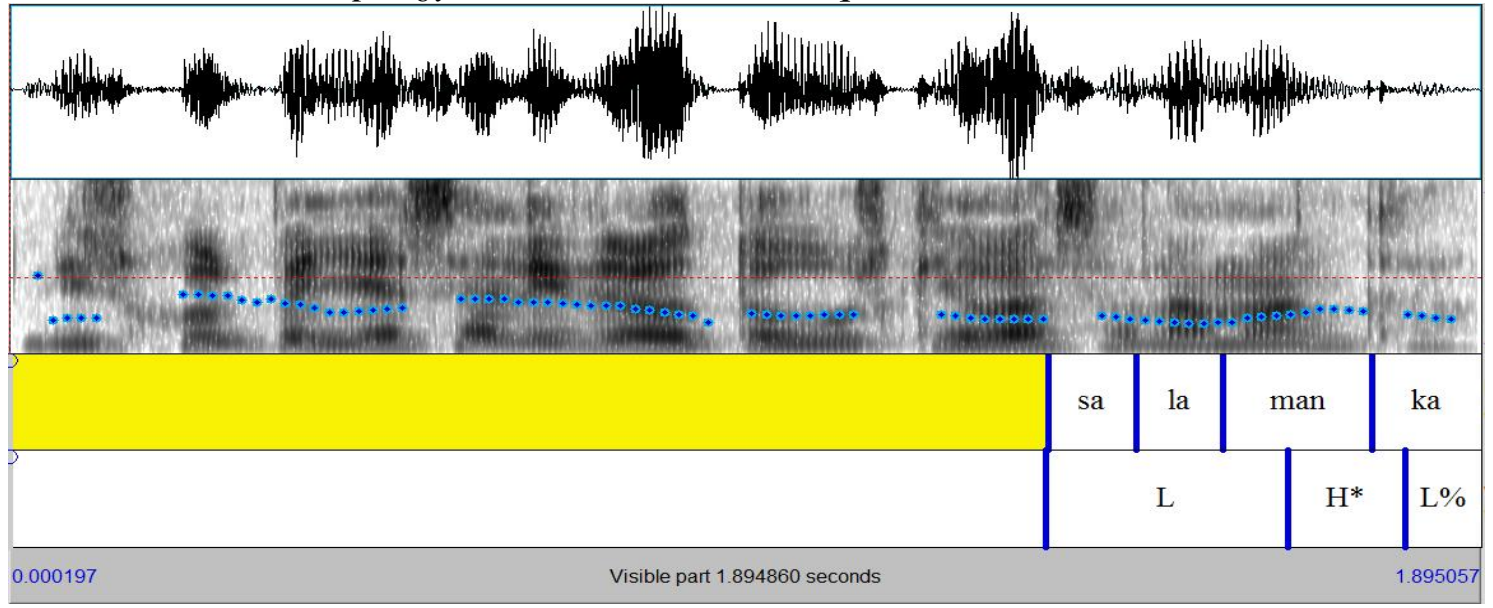

¿Os apetece jugar al ajedrez?

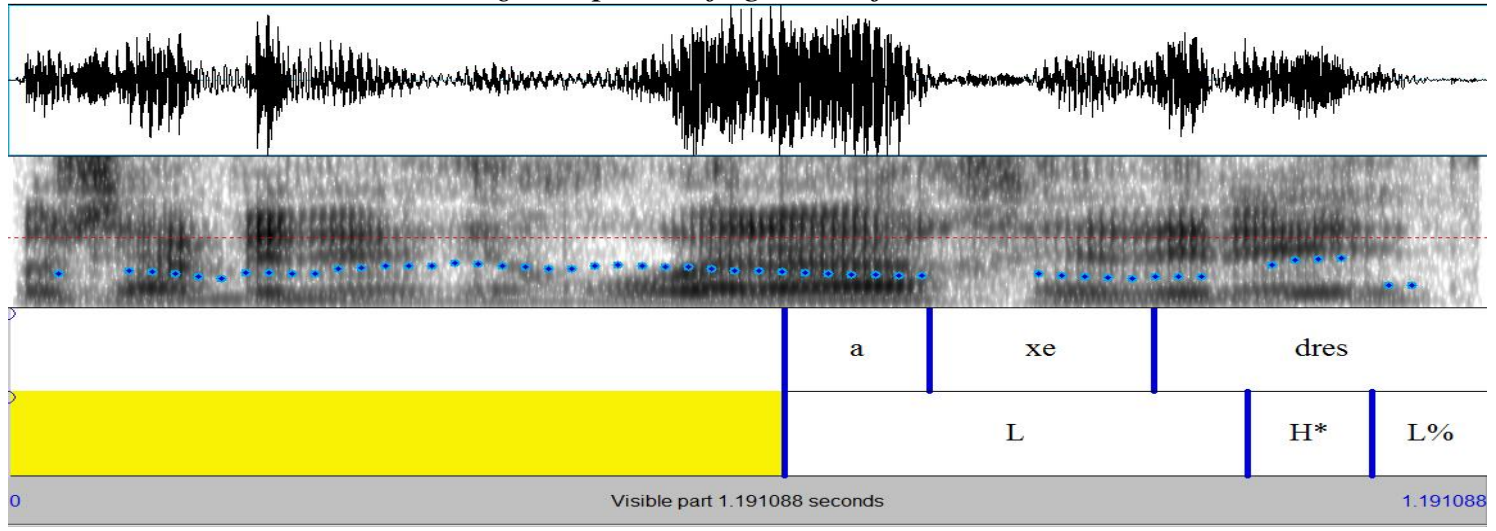

¿Te apetece venir a ver hoy la última película de Antonio Banderas?

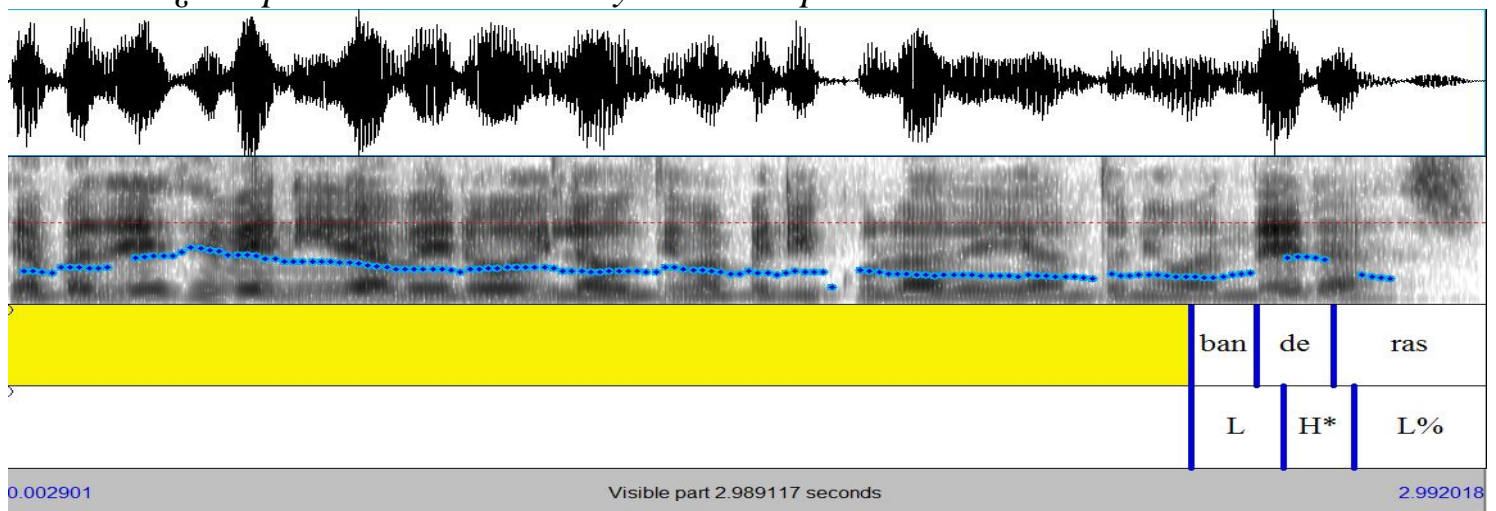


¿Podemos pasar por la heladería?

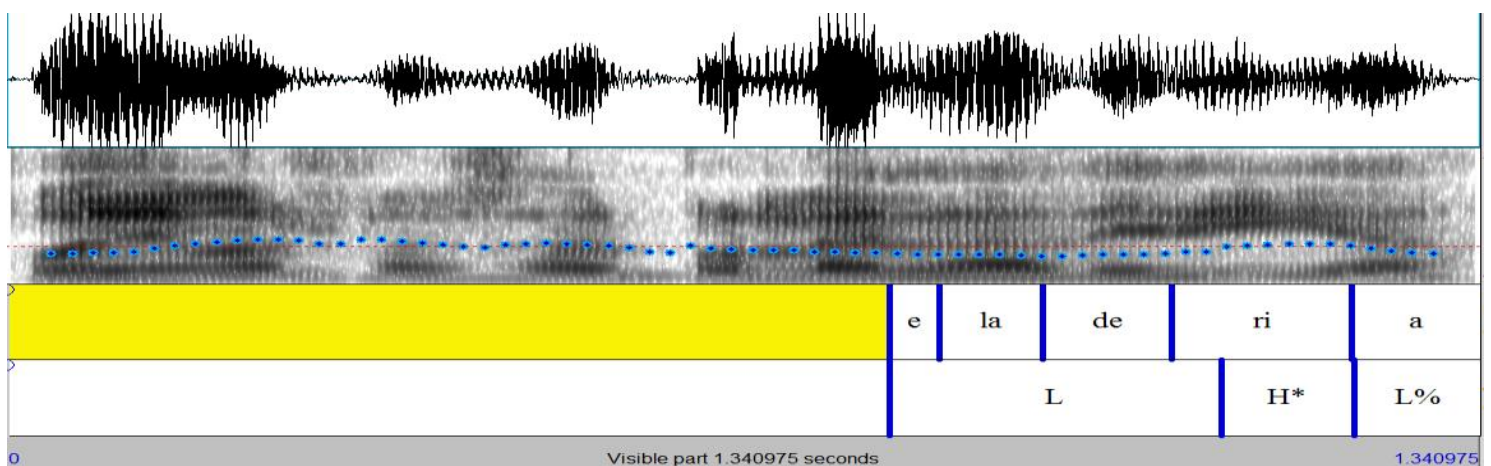

Dolores, ¿has tenido algún problema para hacer los ejercicios de gramática?

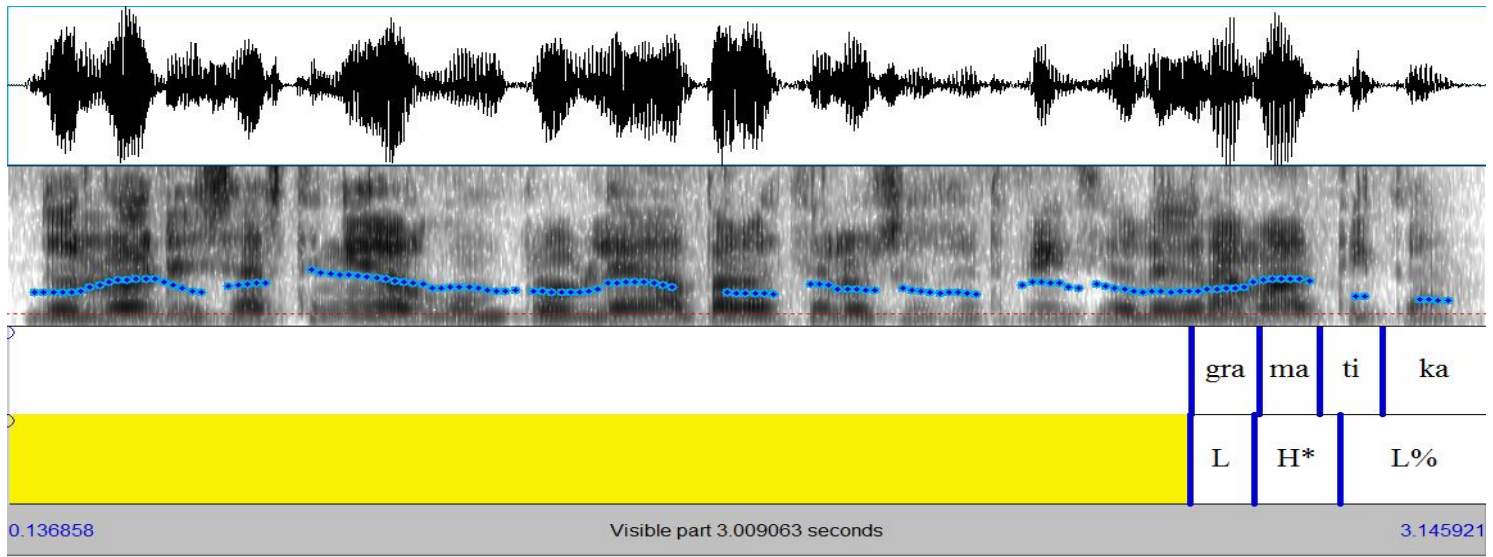

Nesses seis casos exemplificados acima, a configuração da pergunta feita pelo madrilenho é igual à configuração das perguntas totais do $\mathrm{PB}\left(\mathrm{L}+\mathrm{H}^{*} \mathrm{~L} \%\right)$. Seria necessário um estudo mais aprofundado sobre o caso, mas, estando no Brasil há mais de um ano, talvez este madrilenho possa estar com sua pronúncia temporariamente afetada pelo português que ele ouve constantemente fora de sala de aula. Estas interrogativas também podem ter esta configuração distinta, como explicado acima, porque o informante pode tê-las produzido com alguma intenção não necessariamente neutra.

As duas próximas interrogativas absolutas feitas pelo madrilenho são distintas da configuração das perguntas neutras do português porque a sílaba acentuada está no momento em que a curva melódica está baixa (L*). Lucente e Barbosa (2007) lembram que isso ocorre quando há foco de contraste na última palavra do enunciado, ou seja, no núcleo frasal. No primeiro caso, parece que o madrilenho dá ênfase ao ceviche, fazendo com que a curva tenha esta configuração. Já a segunda frase interrogativa, parece que a sílaba fricativa [s] induziu a pergunta a uma queda no final da curva melódica. 
¿Y es muy difícil preparar ceviche?

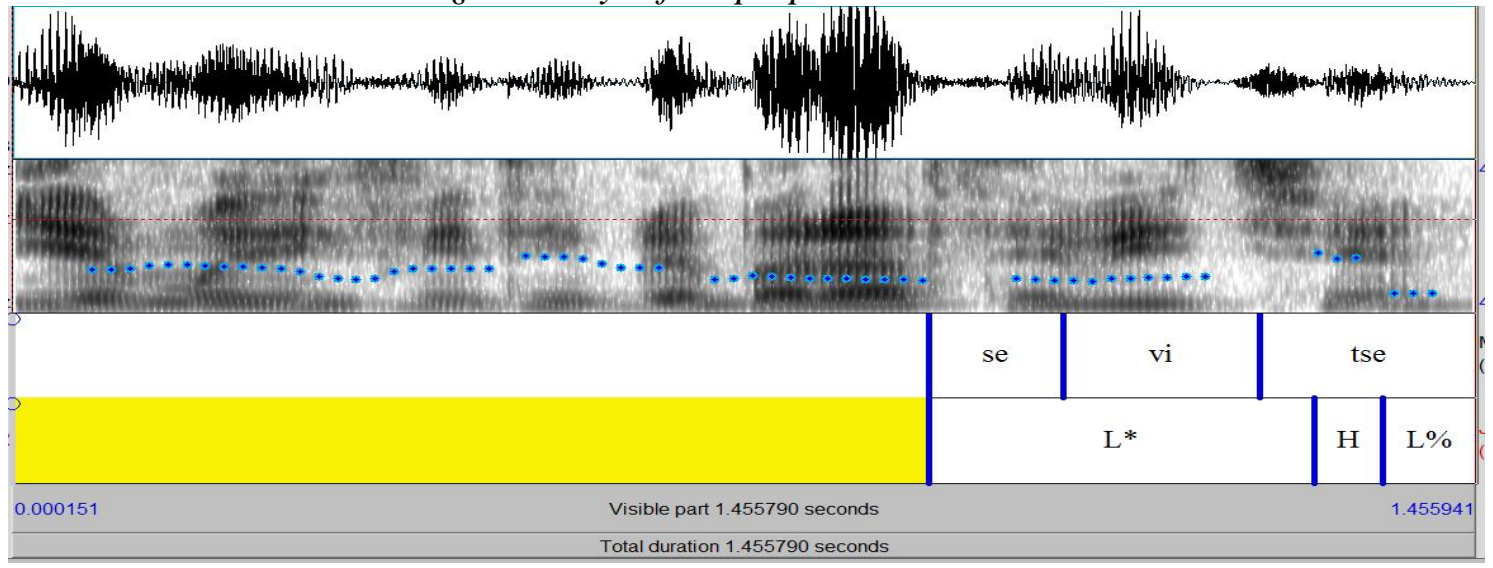

¿Sabe si Lucas tiene ordenador en su casa?

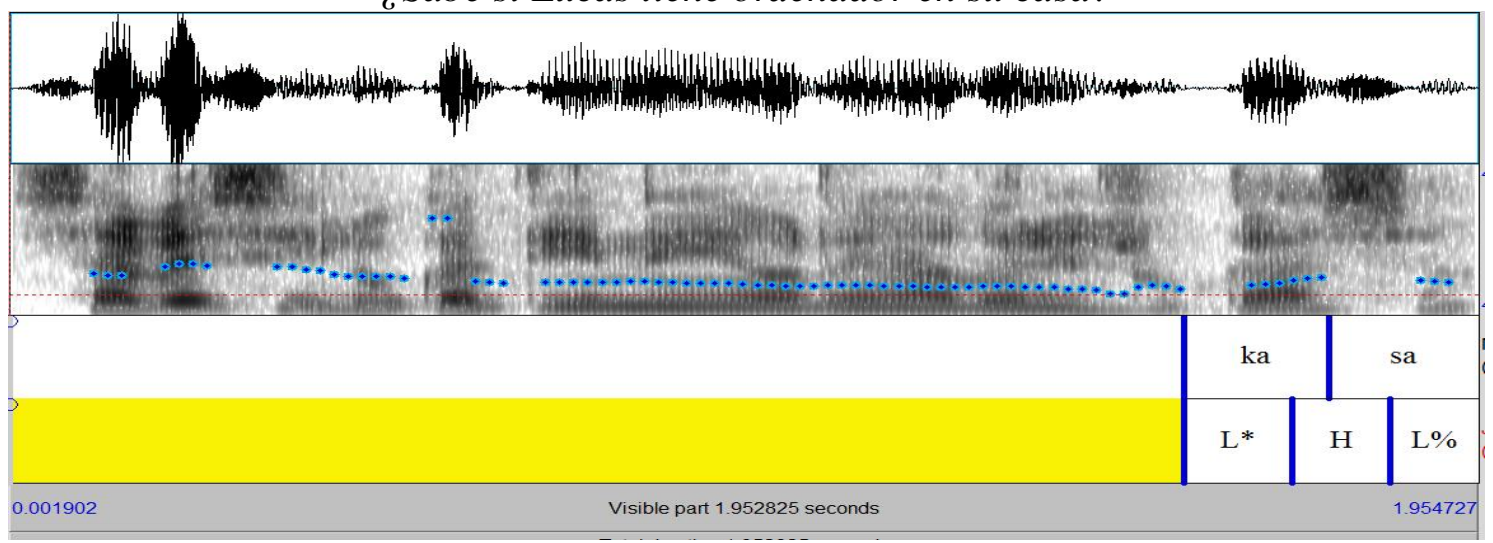

A última interrogativa é a que teve a configuração mais distinta, com a tônica alta, mas com um leve upstep (i), ou seja, a subida não foi tão alta quanto às outras (apenas alguns hertz a mais que a sílaba anterior, ou seja, o range foi de $31 \mathrm{~Hz}$, o que pode ser irrelevante em se tratando de percepção auditiva). Nesse caso também, parece que a fricativa $[\mathrm{s}]$ induziu à queda do final da interrogativa.

¿Quedan plazas para el curso de francés?

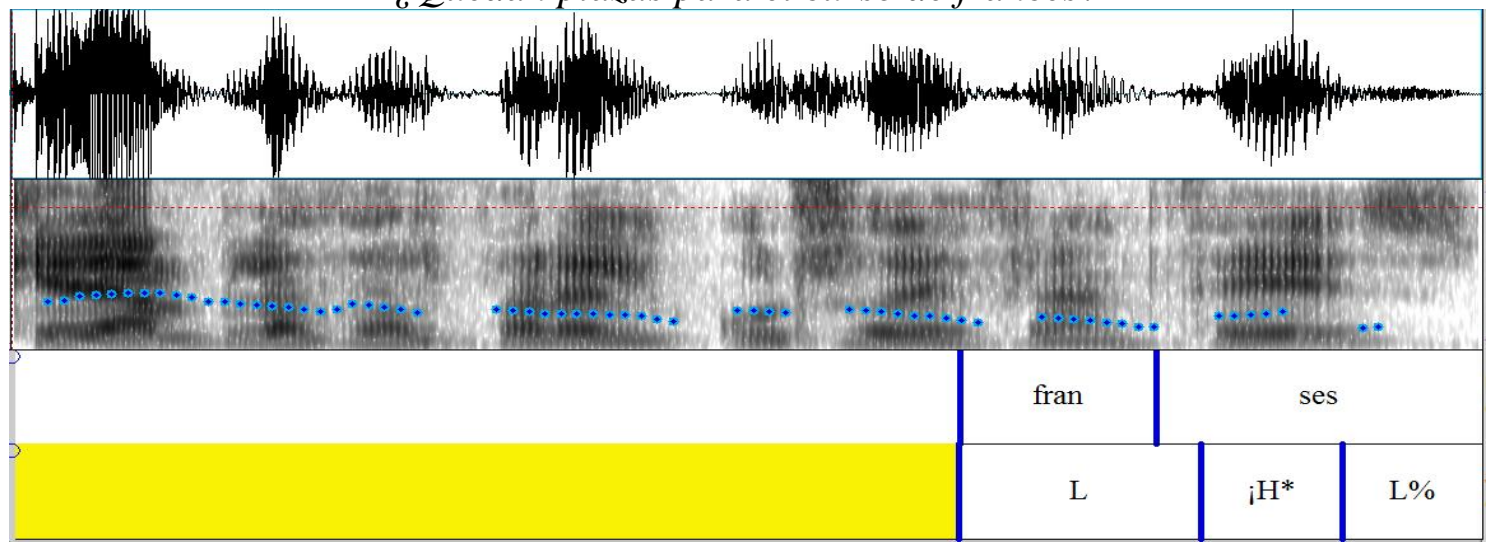


Sobre o informante de LE, as falas induzidas, ou seja, quando as perguntas foram criadas a partir de um dado contexto - tanto as gravações feitas em sala de aula apenas com ele, como as que foram feitas em laboratório - tiveram um resultado bastante semelhante: nas gravadas em sala de aula, de um total de 36, ele produziu 23 (64\%) interrogativas absolutas do espanhol com a prosódia do português e 13 (36\%) com a prosódia do espanhol. Nas feitas em laboratório, de um total de 39, ele produziu $27(69 \%)$ com a prosódia do português e $12(31 \%)$ com a prosódia do espanhol. Isso demonstra que há uma alternância desse informante de LE em produzir interrogativas absolutas do espanhol, ora com a prosódia do PB e ora com a prosódia (adequada) espanhola. Entretanto, a maioria das produções de fala induzida foi com a prosódia do PB. Veja, abaixo, um exemplo de produção de interrogativa absoluta do espanhol feita com a prosódia típica de perguntas totais do $\mathrm{PB}$ e um exemplo com a prosódia do espanhol (respectivamente):
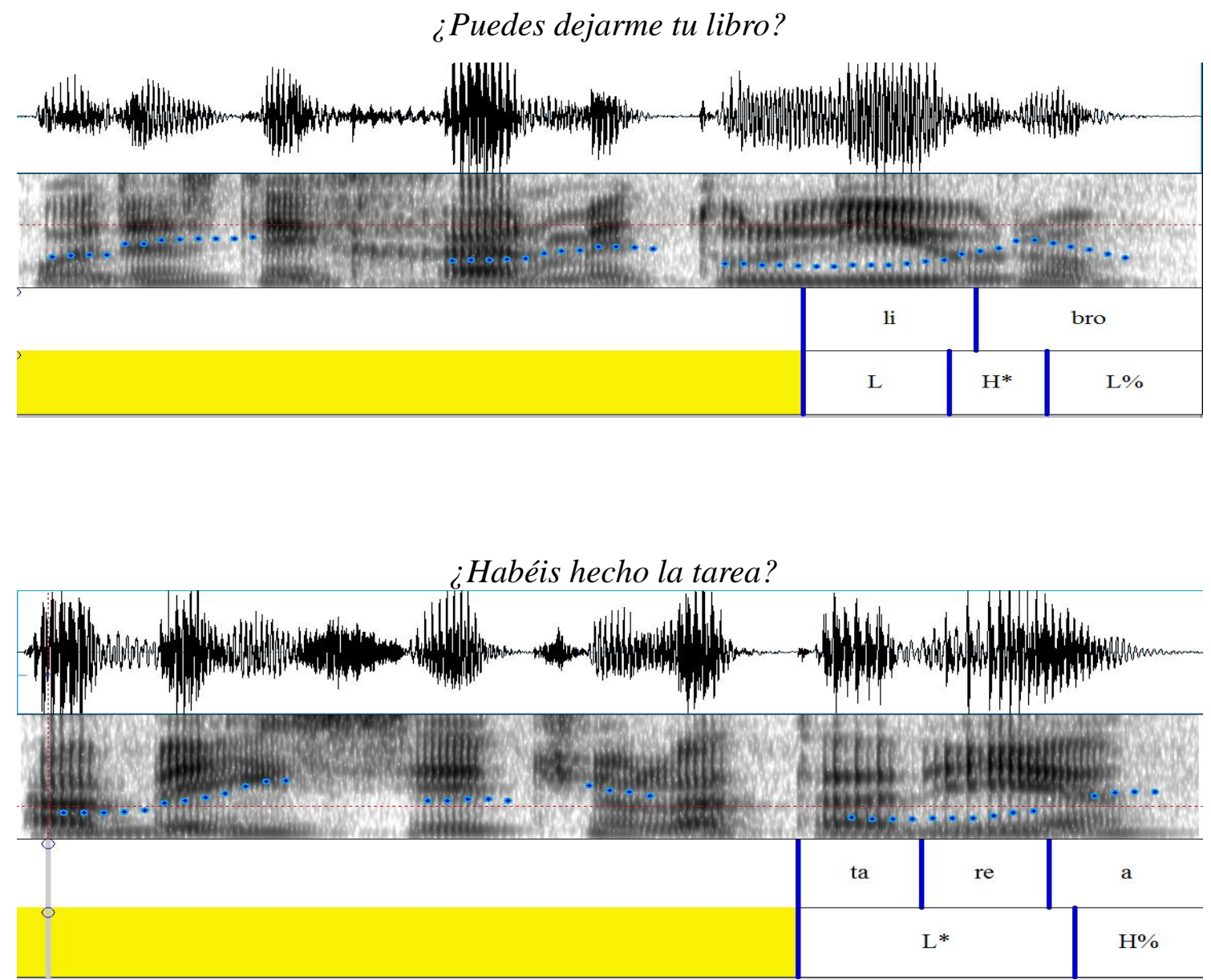
$\mathrm{Na}$ interrogativa ¿Habéis hecho la tarea? a entoação espanhola feita pelo informante de LE foi adequada, terminando com a configuração L*H\%. Já na anterior, ¿Puedes dejarme tu libro?, a configuração da entoação teve interferência da do português brasileiro $(\mathrm{L}+\mathrm{H} * \mathrm{~L} \%)$.

\section{RESULTADOS COM FALA ESPONTÂNEA}

Por outro lado, o informante de LE conseguiu produzir com êxito grande parte das perguntas absolutas com a prosódia própria do espanhol peninsular quando ele estava em situação de fala espontânea, ou seja, das 41 perguntas que ele produziu enquanto dava aulas, 32 (78\%) foram feitas com a prosódia do espanhol e apenas 9 (22\%) foram com a interferência da prosódia do português. Abaixo um exemplo de uma pergunta do espanhol feita, em fala espontânea, com a entoação adequada:

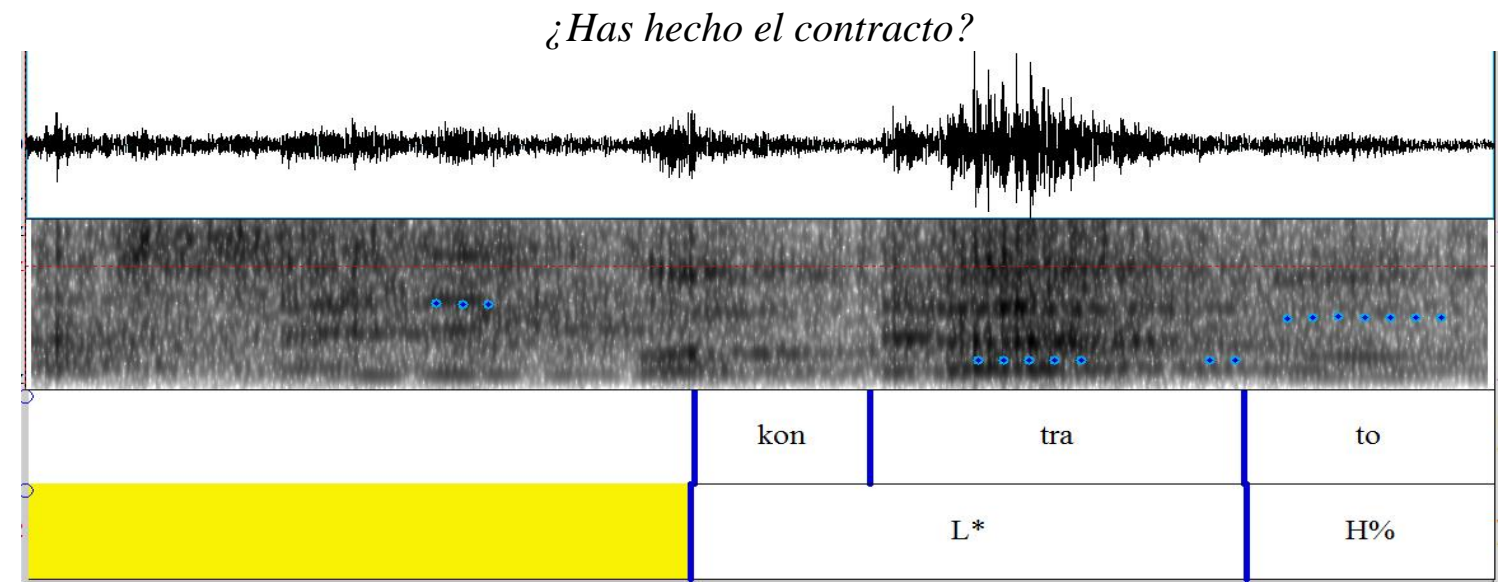

Resumidamente, as 116 interrogativas absolutas totais feitas pelo informante de LE, ficaram distribuídas da seguinte forma:

\begin{tabular}{|c|c|c|c|}
\hline Interrogativas absolutas & Total & $\begin{array}{l}\text { Configuração } \\
(\mathrm{PB})\end{array}$ & $\begin{array}{l}\text { Configuração L*H\% } \\
\text { (espanhol) }\end{array}$ \\
\hline $\begin{array}{l}\text { Em fala espontânea em sala de } \\
\text { aula (o informante ministrando } \\
\text { aulas) }\end{array}$ & 41 & $9(22 \%)$ & $32(72 \%)$ \\
\hline $\begin{array}{l}\text { Em fala induzida (gravações feitas } \\
\text { em sala de aula apenas com o } \\
\text { informante) }\end{array}$ & 36 & $23(64 \%)$ & $13(36 \%)$ \\
\hline $\begin{array}{l}\text { Em fala induzida (gravações feitas } \\
\text { em laboratório) }\end{array}$ & 39 & $27(69 \%)$ & $12(31 \%)$ \\
\hline
\end{tabular}

Os resultados apresentam algumas tendências para os dados encontrados nas gravações do informante de LE. Uma delas é a de que o informante de LE tende a produzir com bastante êxito as perguntas absolutas do espanhol, com a devida entoação, 
quando esse está em situação de fala espontânea e está conversando há algum tempo em espanhol, ou seja, não estava o tempo todo falando em português e, de repente, lê um texto em espanhol e formula uma pergunta isoladamente (como foi feito em fala induzida).

Além do fator espontaneidade e do tempo (duração) de fala em espanhol (as aulas de espanhol duravam cerca de 4 horas e ele conversava com os alunos o tempo todo em espanhol), outra questão que pode ter interferido para que ele produzisse com êxito a entoação espanhola foi o fato de as interrogativas feitas em fala espontânea serem mais breves, com construções gramaticais mais simples e, por diversas vezes, iguais.

Além disso, foi interessante observar que a mesma pergunta feita em diferentes momentos da aula (e até em dias diferentes) apresentou variação de entoação, como a pergunta “¿Alguna duda?", que em alguns casos é feita com entoação espanhola ( $\left.\mathrm{L}^{*} \mathrm{H} \%\right)$ e, em outros, é feita com entoação do $\mathrm{PB}\left(\mathrm{L}+\mathrm{H}^{*} \mathrm{~L} \%\right)$. Essa alteração pode ocorrer, talvez, em decorrência do tempo em que o professor está falando espanhol (o que significa dizer que a interferência da prosódia do PB pode diminuir após algumas horas que este informante ficou falando apenas em espanhol). Esta questão não foi controlada neste estudo, mas, o informante de LE disse que, às vezes, demora para falar espanhol com mais "fluência" logo no início das aulas por causa da troca de idioma (estava falando PB e, de repente, precisa começar a falar espanhol). Esta mudança repentina de idioma pode alterar também a entoação que, neste caso, ficaria adequada conforme o tempo de fala desse informante.

\section{ALGUMAS CONCLUSÕES}

A presente pesquisa atestou a hipótese levantada, de que haveria interferência da prosódia do PB para perguntas totais feitas em espanhol pelo informante de dialeto curitibano, confirmando, assim, o que já foi encontrado em estudos como os de Dias (2012), Pinto (2009) e Oliveira (2011). Isso comprova, por um lado, que independentemente da região brasileira onde vivam, aprendizes de espanhol como LE fazem a entoação das interrogativas com interferência da língua materna (o PB).

Por outro lado, a pesquisa também encontrou dados inesperados e que, até o momento, pelo que se tem conhecimento, não foram explicados. Trata-se do sucesso

\footnotetext{
${ }^{8}$ Alguma dúvida?" Tradução livre da autora.
} 
com que o informante de LE produziu a entoação das interrogativas absolutas quando ele estava em contexto de fala espontânea, dando aulas em espanhol e criando perguntas totais aleatoriamente, sempre que precisava da participação dos alunos em sala de aula. Esse resultado traça um panorama inicial para novas pesquisas, que devem ser mais aprofundadas e focadas nesse aspecto da fala espontânea. Outra questão interessante é que o falante de LE consegue produzir as interrogativas absolutas com sucesso quando está falando a língua estrangeira por um período maior de tempo, o que demonstra que pesquisas pontuais - quando o falante de LE se comunica em sua língua materna e precisa imediatamente trocá-la para a língua estrangeira - essa mudança brusca da língua a ser falada pode interferir na prosódia, distorcendo o objeto de estudo dessa pesquisa.

Parece, então, que o informante de LE tem mais facilidade de produzir a entoação adequada do espanhol quando está em situação de fala espontânea e imerso por algumas horas nesse idioma estrangeiro, mas, para ter certeza disso, serão necessários novos estudos, com um corpus maior de gravação, para se chegar a essa conclusão.

\section{REFERÊNCIAS}

ABRAÇADO J; COIMBRA R; MOUTINHO L. Relação entre acento e entonação em uma variedade do PB: análise de caso de um falante do Rio de Janeiro. In: Moutinho L, Coimbra R, (org). I Jornadas científicas AMPER-POR. Aveiro: Actas; 2007. p.101113.

BOSQUE, I. Nueva gramática de la lengua española: fonética y fonología. Asociación de Academias de la lengua española. Real Academia Española. Barcelona: Espasa Libros, 2011.

COLAMARCO, M.; MORAES, J. A. Você está pedindo ou perguntando: uma análise entonacional de pedidos e perguntas no português do Brasil. Revista de Estudos Linguísticos, Belo Horizonte, 2007, v. 15, n. 2, p. 113-126, jul./dez.

DIAS, E.C.O.; ALVES, M.A. Análise de produção de sentenças interrogativas totais em aprendizes brasileiros de espanhol como língua estrangeira. Journal of Speech Sciences, 2012, p.43-63. 2012

FONT-ROTCHÉS, D. Melodic Analysis of speech (MAS): aplicaciones en la comparación de lenguas. Revista da ABRALIN, 2011, v.1, n. especial, p. 333-366, $1^{\text {a }}$ parte. Disponível em <https://sites.google.com/site/dolorsfontrotches/>. Acesso em 16/08/2012.

LADD, D. R. Phonological representation of pitch in the autosegmental-metrical theory. In: Intonational phonology. Cambridge: Cambridge University Press: 1996, p. 79-112. LUCENTE, L.; BARBOSA, P. A. Notação entoacional do português brasileiro em corpora de fala semi-espontânea e espontânea. Revista Intercâmbio, vol. 16. São Paulo: LAEL/PUC-SP, 2007. 
MORAES, J. The Pitch Accents in Brazilian Portuguese: analysis by synthesis. In: Barbosa, P., Madureira, S. and Reis, C. (eds.). Proceedings of the Speech Prosody 2008: Fourth Conference on Speech Prosody, Campinas, 2008, pp. 389-397.

NAVARRO TOMÁS, T. Manual de entonación española. $4^{\mathrm{a}}$ ed. Madrid: Ediciones Guadarrama, 1974.

NUNES, V. G. Análises entonacionais de sentenças declarativas e interrogativas totais nos falares florianopolitano e lageano. Dissertação, Programa de Pós-Graduação em Linguística, 2011.

OLIVEIRA, A. F.; CANTERO SERENA, F. J. Características da entonação do espanhol falado por brasileiros. In: VII ABRALIN, 2011, Curitiba. Anais do VII Congresso Internacional da ABRALIN, p. 84-98. Artigo disponível em: <http://www.ABRALIN.org/ABRALIN11_cdrom/artigos/Aline_de_Oliveira.PDF>.

Acesso em: 02/08/2012.

PINTO, M. S. Transferências prosódicas do português do Brasil/LM na aprendizagem do espanhol/LE: enunciados assertivos e interrogativos totais. $355 \mathrm{f}$. Tese (doutorado em Estudos Linguísticos Neolatinos), Universidade Federal do Rio de Janeiro, Rio de Janeiro, 2009. Disponível em http://www.letras.ufrj.br/ pgneolatinas/media/bancoteses/ maristeladasilvapintodoutorado.pdf > . Acesso em: 16/08/2012.

QUILIS, A. Estudio Comparativo entre la entonación portuguesa (de Brasil) y la española. Revista de Filología Española. Madrid, v. 68, 1988, p. 33-65.

SOSA, J. M. La entonación del español: su estructura fónica, variabilidad y dialectología. Madrid: Ediciones Cátedra, 1999. 


\begin{abstract}
ANEXO
Segue abaixo os 40 contextos criados para que os informantes elaborassem perguntas absolutas em espanhol a partir do que liam:

1- Antonio desea visitar a Margarete. ¿Cómo él podría preguntarle al portero si ella está en casa?
\end{abstract}

2- Quieres hacerle una sorpresa a Juan antes que él viaje. Pero estás en duda si Juan va a viajar hoy. Pregúntale eso a la madre de Juan.

3- Acabas de ver un accidente entre dos coches. Sabes que en uno de los coches había un niño de 5 años. Pregúntales a los bomberos si el niño murió.

4- Su madre desea mucho ir a misa mañana por la mañana, pero no sabes si la habrá. Llama tú, por teléfono, a la secretaria de la iglesia y pregúntale si habrá misa mañana por la mañana.

5 - Está enamorado de una persona y desea pedirle en casamiento. ¡Hágalo!

6- Sabes que Margarida y Umberto, que son hermanos, pelean todo el tiempo. Por eso estás en duda si a Humberto realmente le gusta su hermana. Pregúntale si le gusta su hermana.

7- Acabas de llegar a tu clase (eres profesor) y necesitas saber si los alumnos han hecho la tarea. Pregúntales.

8- Quieres hacerle una sorpresa a una amiga que va a visitarte. Sabes que a ella le gusta el ceviche, pero no sabes si es un plato difícil de preparar. Pregúntale a tu madre si es difícil hacer ceviche.

9 - Ayer tu amigo Paulo ha comprado un libro que hace años que tú quieres leer. Pregúntale si te presta el libro.

10- Has conocido ayer una persona por la cual te has apasionado. Pregúntale si ella quiere salir contigo hoy por la noche.

11- Estás en el cine y deseas ver una película de Almodóvar. Pregúntale a la mujer de la taquilla si hoy hay alguna película de Almodóvar en el cine.

12- Has exigido de tus alumnos que hagan un trabajo en el ordenador, pero no estás seguro si el estudiante Lucas tiene ordenador en casa. Pregúntale a un amigo de Lucas si él tiene ordenador o no.

13- Tu amiga Leticia cumple años hoy y tú sabes que a ella le gustan los perros. Decidiste, entonces, darle un perro de regalo, pero no sabes si ella ya tiene uno. Pregúntale a su madre si Leticia ya tiene un perro.

14- Has salido de tapas con unos amigos y quieres saber si uno de ellos conoce España. ¡Pregúntale! 
15- Acabas de llegar al terminal de autobuses y quieres saber si de Salamanca ya ha salido. Pregúntale al dependiente.

16- Pregúntales a tus amigos si quieren jugar al ajedrez.

17- Estás viendo todos los juegos de fútbol del Brasil (Copa Confederaciones) y no sabes si el equipo de Brasil juega hoy. Pregúntale a tu amigo.

18- Estás en tu casa y tu mamá acaba de llegar. Ella quiere saber si tú has escuchado el teléfono sonar. ¿Cómo ella te hace esta pregunta?

19- Quieres empezar un nuevo deporte e, incluso, deseas invitar un amigo para practicar el deporte contigo. ¿Cómo le preguntarías si él desea hacer natación contigo?

20- María está cansada de vivir en Brasil, pero tiene dudas de lo que puede hacer. Entonces tú decides preguntarle a ella si viviría en algún país extranjero. ¿Cómo harías la pregunta?

21- Un amigo tuyo está enamorado de Rocío, pero no sabes si ella está casada. ¿Cómo él le preguntaría a Rocío si está casada?

22- En una clase sobre Don Quijote, tú, que eres profesor, necesitas saber si los alumnos saben de Miguel de Cervantes. ¡Hazles la pregunta a ellos!

23- Supiste que tu alumna Dolores tuvo dificultades para hacer los ejercicios de gramática. Confirma con ella si eso es verdad.

24- Un vendedor de papas fritas está en la calle y, al pasar cerca de ti, quiere saber si tú deseas comprar algunas papas. ¿Cómo el vendedor te pregunta eso?

25- Vas a salir con unos amigos y, por eso, necesitas de un autoestop. Pregunta a tu amiga si ella puede darte un autoestop.

26- Mario ha llegado al cine y el cajero le pregunta si tiene el carné de estudiante para el descuento. ¿Cómo el cajero hace la pregunta?

27- Quieres salir de vacaciones con dos amigos y deseas llevarlos a la playa.

Pregúntales si les gusta la playa.

28- Estrenan hoy por la noche la nueva película de Antonio Banderas. Pregúntale a tu amigo si él desea ir contigo al cine.

29- Quieres hacer esquí acuático pero no sabes si es difícil. Pregúntale eso a la guía de la excursión del viaje.

30- El teléfono de tu casa está sonando. Cuando atiendas, quieres saber quién es la persona que está al otro lado de la línea. ¡Pregúntale!

31- Deseas comprar un helado antes de llegar a casa. Como es tu madre quien conduce 
el coche, pregúntale si puede manejarlo hasta una heladería.

32- Has reencontrado un amigo que vivió por muchos años con tus primos. Ahora quieres saber si él sigue en contacto con ellos. ¿Cómo haces esta pregunta?

33- Te duele la cabeza, pero tú sigues sin ir al médico. Tu mamá llega a casa y quiere saber si tú has ido al médico. ¿Cómo tú mamá te pregunta eso?

34- Has encontrado una amiga que desde hace poco está divorciada. Tú quieres saber si ella tiene ganas de hablar sobre como fue el matrimonio. ¡Pregúntale!

35- Has comprado una chaqueta nueva y quieres saber si me ha gustado a mí también. ¡Pregúntame!

36- ¿Qué pregunta haces tú para saber si alguien ha gustado de una propuesta que has hecho?

37- Estás en el super y quieres saber si hay pan. Pregúntale a la dependiente de la panadería.

38- Acabas de llegar a la ciudad donde viven algunos de tus amigos. Ellos te llaman por teléfono para saber si tú estás en el aeropuerto. ¿Cómo hacen la pregunta?

39- Llegaste hoy a Chile para ver la nieve, pero hasta ahora nada. Pregúntale a alguien si nevará mañana.

40- Llegaste a Rusia, pero no sabes hablar nada de ruso. Pregunta, entonces, a alguien de la calle si esta persona habla español. 